\section{USDA's terminator talks}

Members of the US Department of Agriculture (USDA; Washington, DC) Advisory Committee on Agricultural Biotechnology (ACAB) played host in July to another round in the hot debate over the "terminator" technology, which is patented jointly by USDA and the seed company, Delta \& Pine Land. The patents covering this technology broadly protect several genetic manipulations that can render plant seeds sterile or can control gene expression in specific plant tissues. With their main concerns focused on seed sterilization-related issues, activists and some ACAB members are insisting that USDA either abandon these patents or impose various conditions on companies that obtain licenses to develop commercial products through use of this technology. In one non-binding vote, $\mathrm{ACAB}$ members recommended that USDA restrict such licenses to uses in which no heirloom varieties are at stake and the plants being engineered self-pollinate rather than outcross. However, a potentially more far-reaching issue looms for the industry: What happens if USDA and other federal agencies begin imposing revised conditions after patents are granted and well after initial cooperative technology agreements have been signed? USDA officials are expected to announce their plans for terminator-related licensing sometime in the next few months.

\section{Bipartisan caucus revived}

Members of the US House of Representatives announced in July that they were reviving the bipartisan Biotechnology Caucus, renewing a promise to do so from earlier this year. Rep. Robert Ehrlich, Jr. (R-MD), who co-chairs this caucus which already includes more than 60 members, described its principal mission as educating members of Congress "about the safety and potential of biotechnology to enhance agricultural and pharmaceutical products." In addition, the caucus will issue alerts on pending votes of importance to the industry and will serve as a forum on regulatory issues, particularly those concerning food safety. Biotechnology Industry Organization (BIO; Washington, DC) president Carl Feldbaum says that BIO is "delighted that members have Congress have joined together to educate their colleagues on the benefits and importance of biotechnology."

Business and regulatory news briefs written by Aaron J. Bouchie, Liz Fletcher, Jeff Fox, and John Hodgson.

\section{Australia/NZ label GM foods}

The Australia New Zealand Food Standards Council (ANZFSC) has set new rules stipulating that foods containing even a trace of "novel" DNA or protein must be labeled, as must foods with altered characteristics. However, the Council has allowed some exemptions: highly refined foods, such as sugars and oils; foods prepared using GM processing aids and food additives that are not present in the final product (for instance, cheese); food and beverages containing GM flavorings in concentrations of not more than $0.1 \%$; and food prepared at the point of sale-such as in pubs and restaurants. The new standard will also allow a $1 \%$ threshold for accidental "contamination" of an ingredient in a product.

The Codex Alimentarius Commission is expected to set an international standard for labeling of GM foods in 2003. Meanwhile, the $\mathrm{EU}$ and Japan require labeling of foods containing over $1 \%$ and 5\% GM ingredients, respectively, while the US and Canada require labeling only for GM foods with altered characteristics such as increased nutritional value or added allergenic compounds.

$A J B$

\section{Golden handouts on the way}

On August 4,

Monsanto (now part of Pharmacia Corp, Peapack, NJ) announced unconditional royalty-free licenses to its technologies used in the development of

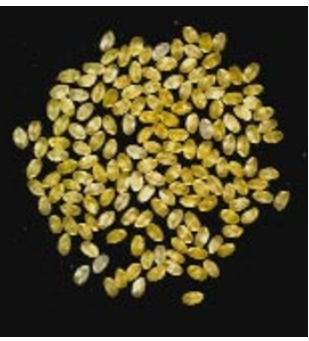

GoldenRice, a genetically modified rice variety enriched with Vitamin A precursors. Developed by Ingo Potrykus (Swiss Federal Institute of Technology, Zurich) and Peter Beyer (University of Freiburg, Germany), production of GoldenRice utilizes 70 patented technologies held by 32 affiliations, making the original goal of free distribution to farmers in developing countries unlikely. However, in May, Zeneca Agrochemicals (London) started the ball rolling through a license agreement with Potrykus and Beyer. In exchange for all rights, Zeneca agreed to support the investors' idea of offering free use of their technology for "humanitarian research. . .and for use and local sale by resource poor farmers in developing countries." Monsanto is the first company to act upon Zeneca's example, but others are expected to follow this month.

\section{GMO roundup}

- The US presidency is no longer a two horse race-now its two horses and a mutant cartoon tiger. Greenpeace, ever conscious of the need to make serious political capital, has thrust Frankentony, its genetically modified caricature of Kelloggs' two dimensional hero, Tony the Tiger, into the presidential election. In the venerable company of Bush and Gore, Frankentony's policies-no GM ingredients in toothrotting cereal products-will undoubtedly start to appear more credible. Its good news, too, that Greenpeace is at last showing itself willing to put its anti-GM stance to the democratic test. If defeated, Frankentony is hoping that his increased profile will give him a shot at the Viagra campaign.

- Ever ahead of the times, the UK's Guardian newspaper continues to get things terribly wrong on genetic modification. On August 10, it reported on a type of GM linseed developed by Alan McHughen at the University of Saskatchewan, Saskatoon, Canada. The variety name of the plant—-"Triffid"—got the reporters so excited that they wrote that the plant was "almost impossible to kill." Indeed, they wrote that McHughen had claimed just that. In fact, McHughen had told the Guardian reporters no such thing. "Triffid" is far from indestructable. An inserted gene allows it to grow in the presence of sulfonylurea in the soil, but it is susceptible to all herbicides usually used to control linseed. The Guardian's triffid story was presented as news, which is odd since the variety was developed in 1988 and was first field tested in 1989. It was approved for commercial release but never actually commercially grown. "I wouldn't have believed how a story could have been so twisted," said McHughen, "unless it happened to me." $J H$

\section{Gene therapy buy}

Gene therapy specialist, Targeted Genetics (Seattle, WA) is to buy another gene therapy company, Genovo (Philadelphia, PA) in a stock swap valued at nearly $\$ 90$ million. The acquisition brings Targeted a new partner, Biogen (Cambridge, MA), which has paid Genovo nearly \$40 million since 1995 for marketing rights to liver- and lung-related genetic therapies. That deal has been extended and is now reportedly worth a potential $\$ 125$ million to the Seattle company. $\quad J H$ 